\title{
Optimization of Agrase production by alkaline Pseudomonas aeruginosa ZSL-2 using Taguchi experimental design
}

\author{
M. Ziayoddin ${ }^{1, *}$, Junna Lalitha ${ }^{1}$, Manohar Shinde ${ }^{2}$ \\ ${ }^{1}$ Department of Biochemistry, Gulbarga University, Gulbarga - 585106, Karnataka, India \\ ${ }^{2}$ Department of Studies and Research in Biochemistry, Tumkur University, \\ Tumkur - 572103, Karnataka, India \\ *E-mail address: ziyagug@gmail.com
}

\begin{abstract}
The culture conditions for the production of extracellular agarase by Pseudomonas aeruginosa ZSL-2 were optimized using One-Factor-At-A-Time combined with orthogonal array design. OneFactor-At-A-Time method investigates the effect of time, temperature, $\mathrm{NaCl}$, carbon sources, nitrogen sources and $\mathrm{pH}$ on agarase production. The optimized culture conditions obtained from the statistical analysis were temperature of $30^{\circ} \mathrm{C}, \mathrm{pH} 8.5, \mathrm{NH}_{4} \mathrm{NO}_{3} 2 \mathrm{~g} \mathrm{~L}^{-1}$ and agar $3 \mathrm{~g} \mathrm{~L}^{-1}$. The $\mathrm{L}_{9}$ orthogonal array design was used to select the fermentation parameters influencing the yield of agarase. The order of the factors affecting the fermentation process was found to be $\mathrm{NH}_{4} \mathrm{NO}_{3}>\mathrm{pH}>$ agar $>$ temperature, with temperature playing a significant role on the agarase production $(\mathrm{p}<0.10)$. The higher yields than those in basal media culture were obtained in the final optimized medium with activity of 0.439 $\pm 0.013 \mathrm{U} \mathrm{ml}^{-1}$. Extracellular agarase hydrolysed agar into a range of oligosaccharides which were analysed by LC-ESI-MS spectrometry as anhydrogalactose, galactose, agarobiose, agarotetrose and agarohexaose.
\end{abstract}

Keywords: Agar, Agarase; Pseudomonas aeruginosa ZSL-2; L 9 orthogonal array design; LC-ESI-MS

\section{INTRODUCTION}

In recent years, bioactivity studies have demonstrated that the oligomer derived from agar or agarose exhibit a variety of physiological activities like hepatoprotective potential (Chen et al. 2006), anti-oxidation (Wang et al. 2004 [36]) and have potential applications in the food, cosmetic (Kobayashi et al. 1997 [1]) and medical industries.Moreover, agarases can be used to prepare protoplasts and extract biological substances such as unsaturated fatty acid, vitamins, carotenoids, and betaine, among others, from algae (Araki et al., 1998 [35]).

The extent of these activities is also correlated with the degree of polymerization (DP) of the galactosyl groups on the neoagaro oligosaccharides (NAOS) and agaro oligosaccharides (AOS). Neoagarobiose (N2) was reported to possess moisturizing and whitening effects on melanoma cells [1]. Neoagarotetraose (N4), derived from porphyran, was reported to be utilized in vitro by intestinal bacteria, which stimulated the growth of Bacteroides, as well as Eubacterium and Lactobacillus [2]. Recently, the prebiotic 
effectiveness of NAOS with DP 4-12 has been confirmed both in vivo and in vitro. They showed augmented growth of Bifidobacterium and Lactobacillus [3].

Agar oligosaccharide can be attained by many methods, including chemical degradation and enzyme hydrolysis. A special enzyme hydrolysing the agar is agarase (agarose 4glycanohy-drolase, E.C.3.2.1.81). Based on the mode of action on agarose, agarases are classified into two groups $\alpha$-agarase and $\beta$-agarase which hydrolyse $\alpha-1,3$ linkages and $\beta-1,4$ linkages in agarose, respectively. Agarases are mainly applied in the production of oligosaccharides from agar. Agarases can also be used to degrade the cell walls of marine algae for the preparation of protoplasts (Chen et al. 1994; Dipak kore et al. 2005). It was also reported that the agarases were used to reclaim DNA from agarose gel (Finkelstein and Rownd 1978; Burmeistera and Lehrachb 1989). Efforts are undertaken recently towards finding more agarases with a high activity from the environment.

Agarases are mainly obtained from marine bacteria. To date, a number of microorganisms have been reported to secrete agarase, mainly in a marine environment, either in the sea water, in marine sediments or associated to red algae [4,5]. The agarase producing bacteria are also isolated from nonmarine environments, like the ones from low-land river [6], soil [7,8] and plant root [9]. There are limited number of studies which have investigated the optimization of culture conditions for agarase-producing microbes [10-16]. Optimal culture conditions for agarase-producing Pseudomonas $s p$. by statistical approach have not been reported.

In present investigation we report optimization of fermentation conditions for the production of agarase by two steps. First, optimization by "One-Factor-At-A-Time" (OFAT) involves changing one of the independent variables, temperature, $\mathrm{pH}$, nitrogen source etc. while fixing the others at certain levels, and second, further optimization by Taguchi experimental design. The basic principle of the Taguchi method serves as screening filters that examine the effects of many process variables and identify those factors that have major effects on process by using a few experiments and also LC-ESI-MS analysis of agar degraded products.

\section{MATERIALS AND METHODS}

\section{1. Microorganism}

An agarolytic Pseudomonas aeruginosa ZSL-2 strain isolated from marine environment was inoculated in minimal mineral salts (MMS) medium composed of $0.38 \mathrm{~g} / \mathrm{L} \mathrm{K}_{2} \mathrm{HPO}_{4}$; $0.20 \mathrm{~g} / \mathrm{L} \mathrm{MgSO}_{4} ; 0.05 \mathrm{~g} / \mathrm{L} \mathrm{FeCl}_{3} ; 1.0 \mathrm{~g} / \mathrm{L} \mathrm{NH}_{4} \mathrm{NO}_{3}$ and $3.0 \mathrm{~g} / \mathrm{L}$ agar. This strain was routinely maintained and stored at $4{ }^{\circ} \mathrm{C}$ on MMS-agar slants in the laboratory. Seed culture was prepared from $24 \mathrm{~h}$ grown culture on MMS liquid broth at $180 \mathrm{rpm}$ and $37{ }^{\circ} \mathrm{C}$ as reported earlier [17].

\section{2. Agarase assay}

Agarase activity was determined by neocuproine method as described by Dygert et al., [18]. The assay mixture of $1 \mathrm{ml}$ contained $20 \mathrm{mM}$ Tris- $\mathrm{HCl}$ buffer $(\mathrm{pH} 8.0), 0.5 \mathrm{ml}$ of agrose $\left(0.1 \% \mathrm{w} / \mathrm{v}\right.$ in Tris-HCl buffer) and $50 \mu \mathrm{l}$ suitably diluted enzyme at $40{ }^{\circ} \mathrm{C}$. One unit of the enzyme activity was defined as the amount which liberates $1 \mu \mathrm{mol}$ galactose equivalent per minute under assay condition. The protein content of the enzyme solution was determined by the Lowry method using Bovine serum albumin as standard protein [19]. 


\section{3. Optimization of culture parameters for the production of extracellular agarase by "one-factor-at-a-time" (OFAT)}

The optimization of fermentation conditions were carried out based on stepwise modification of the governing parameters for agarase production. They include fermentation period, $\mathrm{pH}$, temperature, $\mathrm{NaCl}$, carbon source and nitrogen sources. The optimum culture condition obtained in previous step was used in next step.

\section{3. 1. Effect of culture conditions on agarase production}

The $P$. aeruginosa ZSL-2 was inoculated into the MMS medium supplemented with agar $(0.3 \% \mathrm{w} / \mathrm{v})$ and incubated. A $1 \mathrm{ml}$ exponential growth phase culture was inoculated into a fresh $250 \mathrm{ml}$ Erlenmeyer flask containing $50 \mathrm{ml}$ MMS medium supplemented with agar $(0.3 \% \mathrm{w} / \mathrm{v})$. In order to check the effect of fermentation period the flasks were incubated on a rotary shaker at $170 \mathrm{rpm}$ and $37^{\circ} \mathrm{C}$ for $60 \mathrm{~h}$. The effect of incubation period was analysed by withdrawing $2 \mathrm{ml}$ of culture medium aseptically at different intervals. To study the effect of initial $\mathrm{pH}$, the culture inoculated media flasks were individually incubated at different $\mathrm{pH}$ (pH 5-11). To check the effect of temperature, the flasks were incubated at different temperature such as $20,25,30,37$ and $40{ }^{\circ} \mathrm{C}$. Similarly the effect of ionic strengths $(0-5 \%$ $\mathrm{NaCl}, \mathrm{w} / \mathrm{v}$ ) was also investigated.

\section{3. 2. Effect of carbon and nitrogen sources on agarase production}

To study the effect of different nitrogen sources on agarase production, $\mathrm{NH}_{4} \mathrm{NO}_{3}$ in the medium was replaced with different organic nitrogen sources $(0.1 \%, \mathrm{w} / \mathrm{v})$ such as peptone, yeast extract, beef extract, and inorganic nitrogen sources $\left(1 \%\right.$, w/v) such as $\mathrm{KNO}_{3}, \mathrm{NH}_{4} \mathrm{Cl}$, $\mathrm{NaNO}_{3}$ or $\left(\mathrm{NH}_{4}\right)_{2} \mathrm{SO}_{4}$ and fermentation was carried out as described earlier. The influence of carbon source on the agarase production was analysed by growing $P$. aeruginosa ZSL-2 in the MMS medium supplemented with various carbon sources $(0.2 \%$ to $0.5 \%$, w/v) such as glucose, galactose, fructose, lactose, sucrose, mannose, maltose and agar alone or the said carbon sources were co-supplemented with agar.

\section{4. Optimization of agarase production by orthogonal array testing strategy (OATS)}

Based on the one-factor-at-a-time, an $\mathrm{L}_{9}\left(3^{4}\right)$ orthogonal array method was used to determine optimal medium conditions for caarrageenase production. This enables to determine which process variables affect the response. The level-setting values of the factors used in the orthogonal array design are shown in Table 3. The four variables, agar, $\mathrm{NH}_{4} \mathrm{NO}_{3}$, temperature and $\mathrm{pH}$ with three concentration levels were used. The experiments were carried out in $250 \mathrm{ml}$ Erlenmeyer flasks containing $50 \mathrm{ml}$ MMS medium. The agarase activity of each flasks was assayed after $24 \mathrm{~h}$ of incubation and analysed statistically by ANOVA.

\section{5. LC-ESI-MS analysis of agar oligosaccharides}

The hydrolysed product of agar by $P$. aeruginosa ZSL-2 supplemented in the growth medium were analyzed by LC- ESI-MS as reported by Baswaraj et al., [20]. Briefly, a 1-ml of the culture medium was withdrawn, cooled to $4{ }^{\circ} \mathrm{C}$ and was centrifuged for $15 \mathrm{~min}$ at $14000 \mathrm{rpm}$. A $500 \mu \mathrm{l}$ of clarified culture supernatant was extracted by $80 \%$ methanol $(-20$ $\left.{ }^{\circ} \mathrm{C}\right)$, and evaporated to dryness by a vacuum manifold. The residue was then re-dissolved in $100 \mu \mathrm{l}$ of $80 \%$ methanol and was filtered through a $5 \mathrm{kDa}$ centricon filter and the filtrate obtained was transferred to an autosampler vial. Ten microliters of culture supernatant 
filtered through $0.22 \mu$ syringe filter was injected through auto sampler into a $150 \mathrm{~mm} \times 4$ $\mathrm{mm}$ i.d, $5 \mu$ phenomenex C-18 RP-column (thermostated at $40^{\circ} \mathrm{C}$ ) at flow rate $1 \mathrm{ml} \mathrm{min}^{-1}$. LC is synchronized with mass Q TRAP 4000 MS-MS (Applied Biosystems MDS-SCIX). LCESI-MS data acquisition was carried out at $22 \mathrm{~min}$. EMS spectra were generated from the TIC. Spectra were recorded in negative mode between $\mathrm{m} / \mathrm{z} 50$ and 1200 . Identification was carried out with AB's Analyst 1.2.2 software.

\section{RESULTS AND DISCUSSION}

\section{1. Optimization of culture parameters for the production of extracellular agarases from}

\section{P. aeruginosa ZSL-2 by "one-factor-at-a-time" (OFAT)}

A typical growth profile and agarase production by $P$. aeruginosa ZSL-2 (Fig. 1) reveals that the agarase production in extracellular medium was observed after $12 \mathrm{~h}$ of incubation, which increased with an increase in the incubation period. Maximum agarase activity $(0.166 \mathrm{U} / \mathrm{ml})$ was observed in late $\log$ phase at $24 \mathrm{~h}$ incubation, thereafter the agarase production decreased. The agarase production in $P$. aeruginosa $\mathrm{ZSL}-2$ was maximum $(0.179 \mathrm{U} / \mathrm{ml})$ when the bacterium was grown at $30{ }^{\circ} \mathrm{C}$ (Fig. 2). The agar utilising bacterium T. agarivorans is reported to grow over a temperature range of 20 to $35^{\circ} \mathrm{C}$, with an optimum temperature of 25 ${ }^{\circ} \mathrm{C}$ [21] and growth of $P$. agarivorans was observed over a range of 20 to $30{ }^{\circ} \mathrm{C}$, with an optimum at 20 to $25^{\circ} \mathrm{C}$ [22].

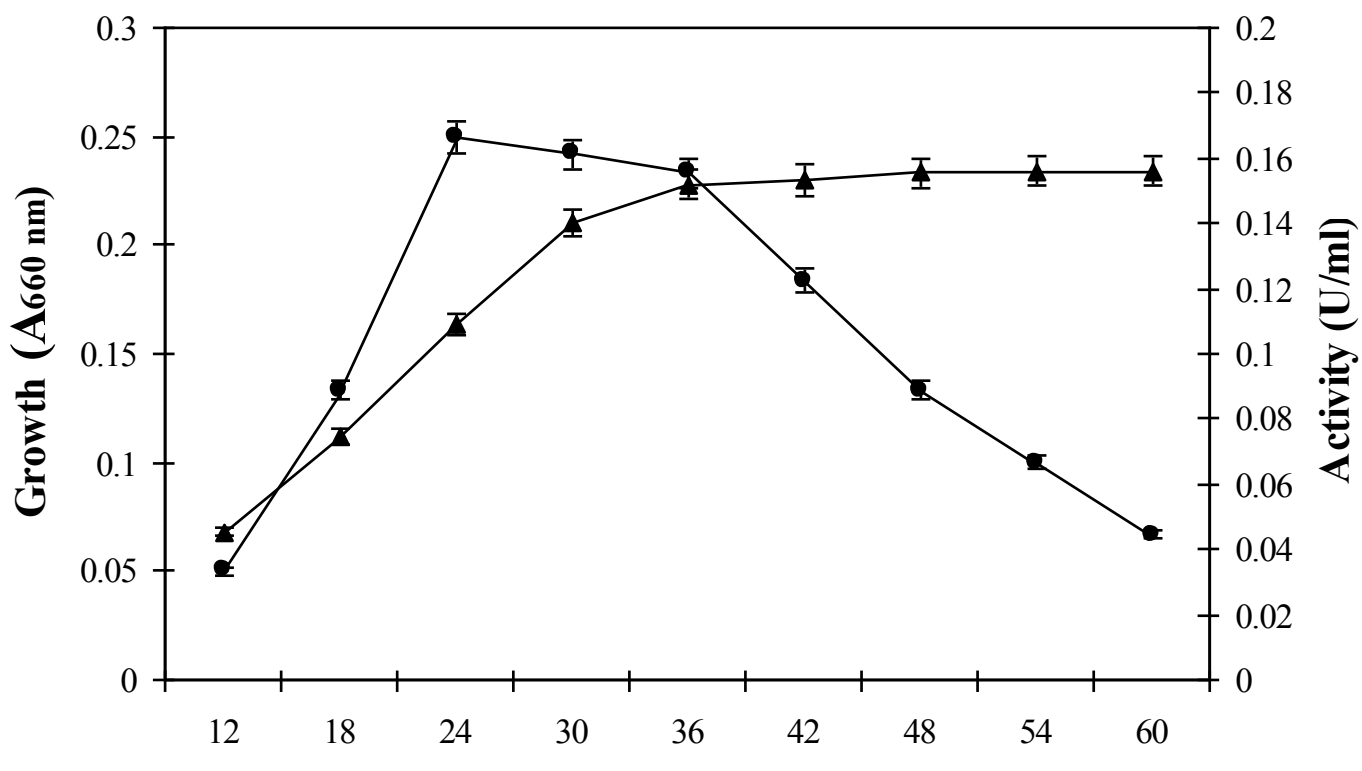

Time (h)

Fig. 1. Effect of incubation time on growth $(\boldsymbol{\Delta})$ and production $(\bullet)$ of extracellular agarase by Pseudomonas aeruginosa ZSL-2. 


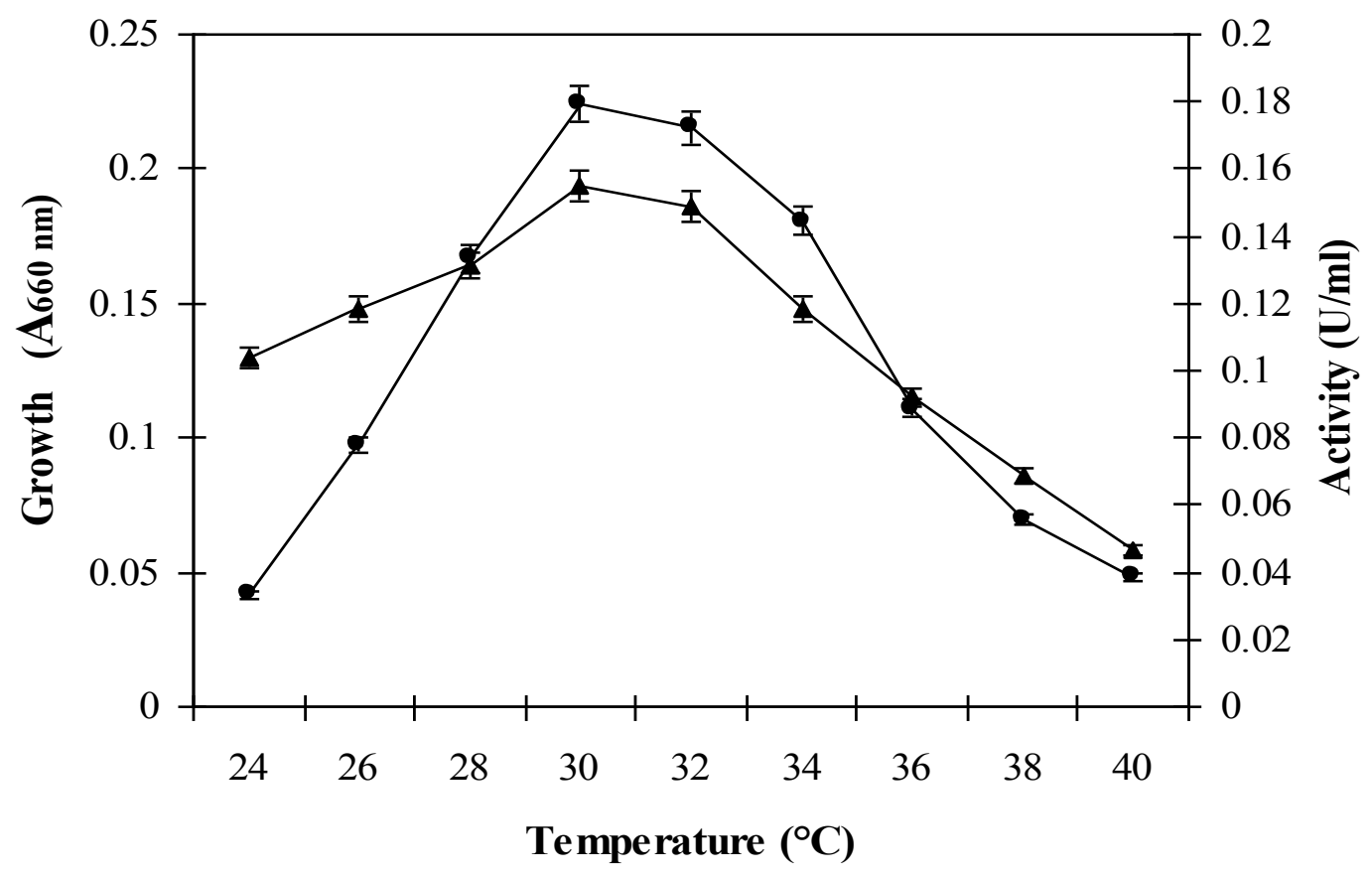

Fig. 2. Effect of temperature on growth $(\boldsymbol{\Delta})$ and production $(\bullet)$ of extracellular agarase by Pseudomonas aeruginosa ZSL-2.

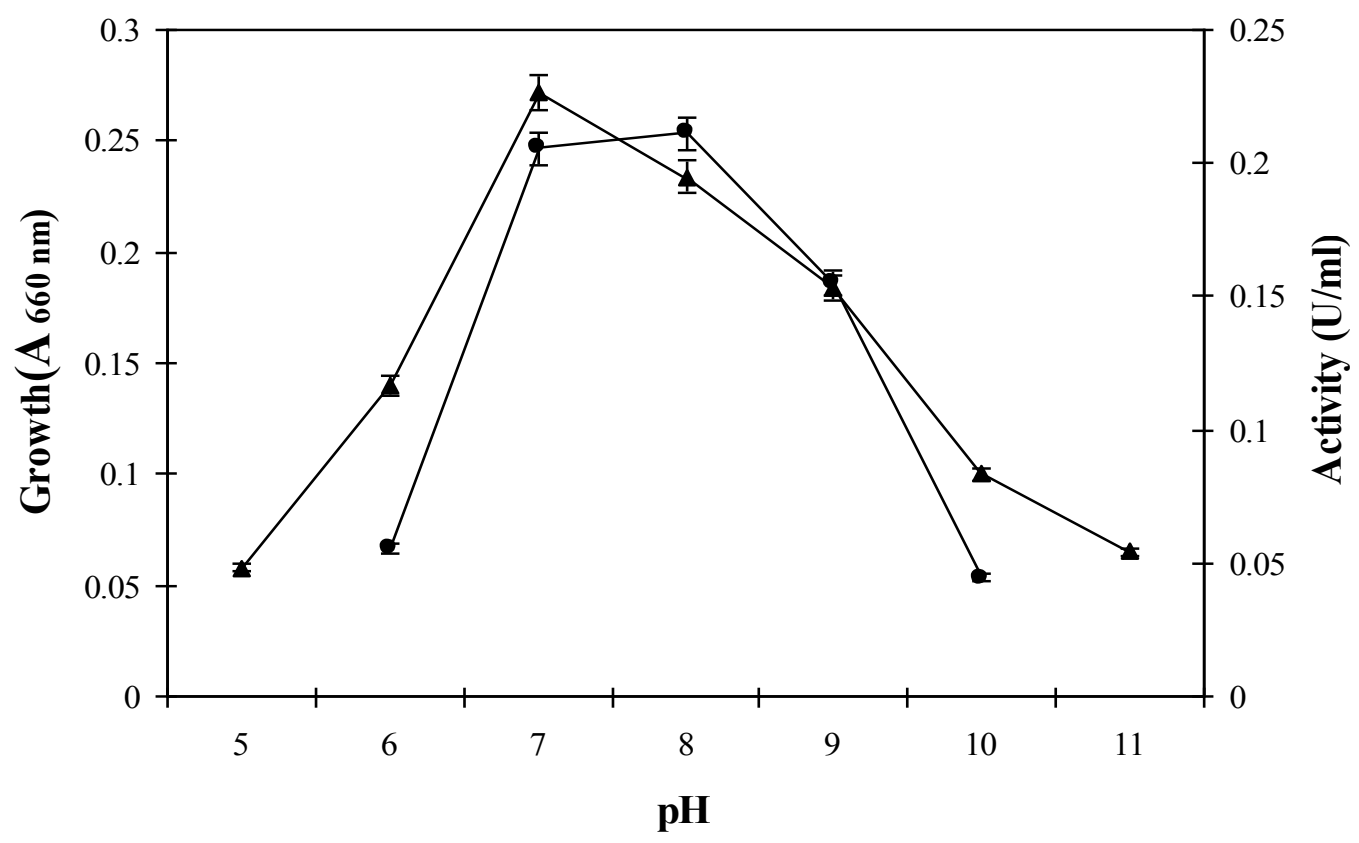

Fig. 3. Effect of pH on growth $(\boldsymbol{\Delta})$ and production $(\bullet)$ of extracellular agarase by Pseudomonas aeruginosa ZSL-2. 
However; agarase was produced in the culture medium at $\mathrm{pH}$ range of 5.0-11.0 and maximum agarase production $(0.211 \mathrm{U} / \mathrm{ml})$ was observed at $\mathrm{pH}$ 8.0. (Fig. 3). Most agarolytic bacteria those are reported to date grew at $\mathrm{pH}$ range between 6.5 and 7.8. However, the Agarivorans sp. HZ105 is reported to grew at the broad $\mathrm{pH}$ range of 6.0-11.0, and optimally at about $\mathrm{pH} 8.0$ [13]. The Alteromonas strain 2-40 is reported to grow at $\mathrm{pH}$ range between 5.0 and 9.2 and optimally at $\mathrm{pH} 7.5$ [23], The Pseudomonas aeruginosa AG LSL-11 is reported to grow in the $\mathrm{pH}$ range 5.0-11.0 and optimally at $\mathrm{pH} 8.0$ [10]. Acinetobacter $s p$., AG LSL-1 grew at $\mathrm{pH}$ range from $\mathrm{pH} 4.0$ to 9.0, and optimally at $\mathrm{pH} 7.0$ [24]. However, it was reported $P$. agarivorans as a slightly alkali tolerant with $\mathrm{pH}$ growth range of 6 to 9 and with an optimum $\mathrm{pH}$ of 8 to 9 [22]. As we know, the natural seawater is of a weak alkaline $\mathrm{pH}$, thus it is reasonable that the marine isolates show optimized growth at slightly alkaine $\mathrm{pHs}$ and agarases derived from marine bacteria show maximum agarse production in those conditions. The effect of sodium chloride $(0-5 \%, \mathrm{w} / \mathrm{v})$ on agarase production revealed that the production of agarase by $P$. aeruginosa ZSL-2 was found to be slightly increased with increase in concentration of $\mathrm{NaCl}$ up to $1 \%(\mathrm{w} / \mathrm{v})$, beyond which there was sharp decline in the secretion. At $4 \% \mathrm{NaCl}$, the considerable agarase production was not observed though the bacterium was able to grow (Fig 4).

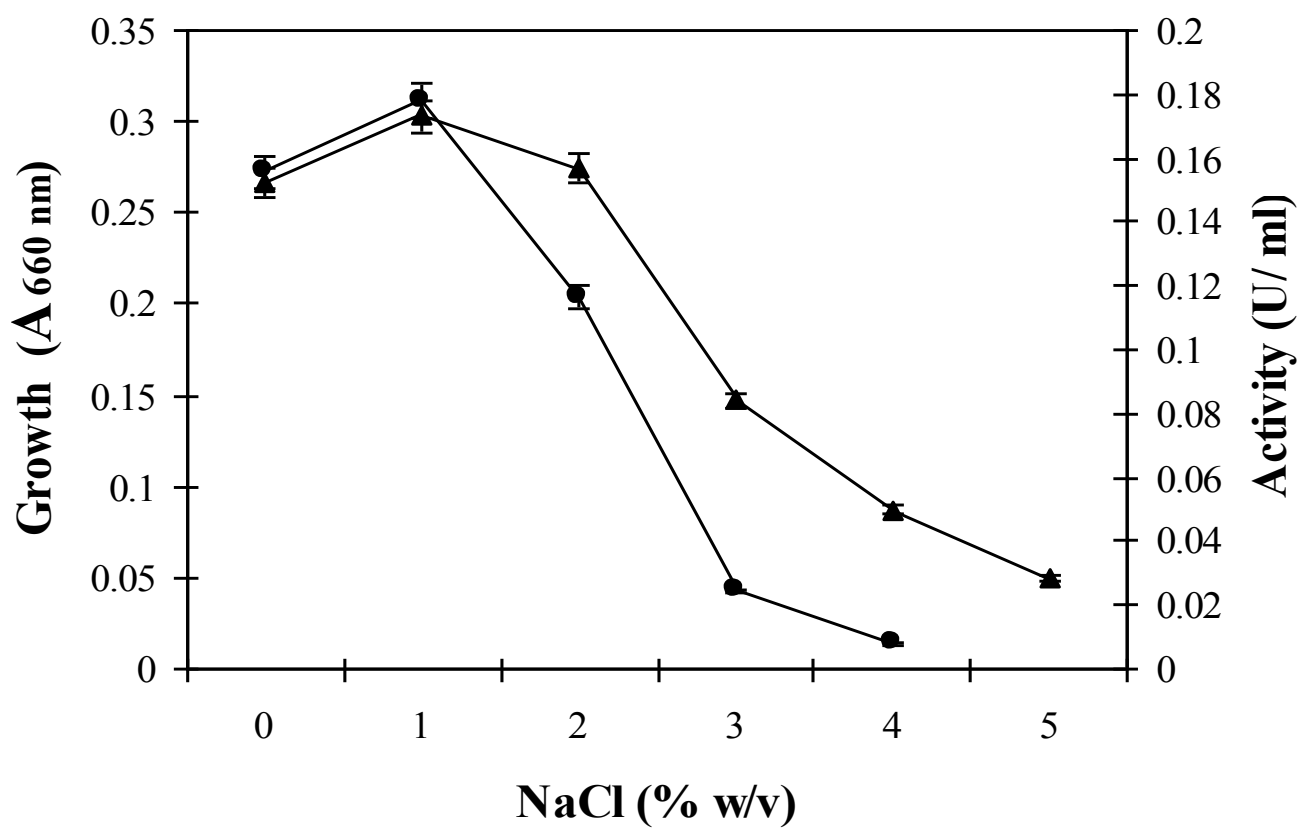

Fig. 4. Effect of $\mathrm{NaCl}$ on growth $(\mathbf{\Delta})$ and production $(\bullet)$ of extracellular agarase by Pseudomonas aeruginosa ZSL-2.

It is commonly assumed that the marine bacteria, since they live in the sea, most of them are salt-tolerant. Most agarolytic bacteria, viz., Pseudomonas atlantica, [25], Pseudomonas AP5333, [26], Pseudoalteromonas antartica strain N-1 [27], Alteromonas strain 2-40 [23], Alteromonas sp. strain C-1 [28], Vibrio sp strain JT0107 [29], those are isolated from marine source are reported to have a specific requirement of sodium chloride (2.5\%) for their growth. Agarolytic bacterium Bacillus cereus ASK 202 is reported to grow well even at $5 \% \mathrm{NaCl}$ concentration [30]. The Pseudomonas aeruginosa ZSL-2 grows better 
at $1 \% \mathrm{NaCl}$ concentration and unlike other agarolytic marine Pseudomonads, Pseudomonas aeruginosa ZSL-2 do not demand for sodium chloride as a specific requirement, moreover, even in absence of which, the bacterium grows well and produces extracellular agarases. Similar observations are reported for $P$. aeruginosa AG LSL 11 [10].

An understanding of the influence of nitrogen source on the growth of $P$. aeruginosa ZSL-2 was derived by growing the later in the fermentation medium containing different nitrogen sources such as, $\mathrm{KNO}_{3}, \mathrm{NH}_{4} \mathrm{Cl}, \mathrm{NaNO}_{3}$ or $\left(\mathrm{NH}_{4}\right)_{2} \mathrm{SO}_{4}$ and supplemented with agar $(0.3 \%, \mathrm{w} / \mathrm{v})$ as sole carbon source. The growth of the bacterium was found to be optimum in the medium supplemented with $\mathrm{NaNO}_{3}$ or $\mathrm{NH}_{4} \mathrm{NO}_{3}$ as nitrogen source and agar as the carbon source. The production of agarase $(0.354 \mathrm{U} / \mathrm{ml})$ was found to maximum in the medium, which had received $\mathrm{NH}_{4} \mathrm{NO}_{3}$ as nitrogen source. The production of agarase was found to be less in the fermentation medium supplemented organic nitrogen sources, however peptone and beef extract served as the good sources than the other organic nitrogen, but less agarase production was observed (Table 1).

Table 1. Effect of nitrogen sources on the growth and production of extracellular agarase by Pseudomonas aeruginosa ZSL-2.

\begin{tabular}{lcc}
\hline $\begin{array}{l}\text { Nitrogen } \\
\text { source }\end{array}$ & $\begin{array}{c}\text { Growth } \\
\left(\mathrm{A}_{660 \mathrm{~nm}}\right)\end{array}$ & $\begin{array}{c}\text { Agarase activity } \\
\left(\mathrm{U}^{-} l^{-1)}\right.\end{array}$ \\
\hline $\mathrm{NH}_{4} \mathrm{NO}_{3}$ & 0.441 & 0.354 \\
$\mathrm{KNO}_{3}$ & 0.372 & 0.234 \\
$\mathrm{NH}_{4} \mathrm{Cl}$ & 0.177 & 0.0743 \\
$\mathrm{NaNO}_{3}$ & 0.409 & 0.296 \\
$\left(\mathrm{NH}_{4}\right)_{2} \mathrm{SO}_{4}$ & 0.201 & 0.173 \\
$\mathrm{Peptone}$ & 2.084 & 0.112 \\
Yeast extract & 1.011 & 0.09836 \\
Beef extract & 2.104 & 0.082 \\
\hline
\end{tabular}

* Fermentation conditions: MMS media containing one of the nitrogen sources, supplemented with agar at $\mathrm{pH} 8$, temperature $30{ }^{\circ} \mathrm{C}$ after $24 \mathrm{~h}$ of incubation

The observed results indicated that $\mathrm{NH}_{4} \mathrm{NO}_{3}$ as a sole nitrogen source supported the optimum growth and maximum enzyme production, thus nitrogen was found to be an essential element for the production of the agarolytic enzyme. This effect had been reported with a similar observation using yeast extract as a nitrogen source [10,14].

Agarase production was observed in the fermentation media supplemented with agar (Table 2). The bacteria grew well utilizing other simple sugars, while agarase production was not observed. On the other hand agarase production was observed when simple sugars were co-supplemented to agar containing fermentation media.

The results revealed that agarase production was inducible only in presence of agar when the simple sugars alone were included in the medium, although good growth was 
observed, agarase production was not occurred in the medium. Co-supplementation of other simple sugars to agar found to reduce the production slightly though luxuriant growth by utilizing simple sugars was observed.

Table 2. Effect of carbon sources on growth and production of extracellular agarase by Pseudomonas aeruginosa ZSL-2.

\begin{tabular}{lccccc}
\hline $\begin{array}{l}\text { Carbon } \\
\text { source }\end{array}$ & $\begin{array}{c}\text { Growth } \\
\left(\mathrm{A}_{660}\right)\end{array}$ & $\begin{array}{c}\text { Agarase } \\
\text { production } \\
(\mathrm{U} / \mathrm{ml})\end{array}$ & $\begin{array}{c}\text { Co-Supplimentation } \\
\text { of sugars }\end{array}$ & $\begin{array}{c}\text { Growth } \\
\left(\mathrm{A}_{660}\right)\end{array}$ & $\begin{array}{c}\text { Agarase } \\
\text { production } \\
(\mathrm{U} / \mathrm{ml})\end{array}$ \\
\hline Agar & 0.438 & 0.37 & Agar & 0.465 & 0.374 \\
Glucose & 1.123 & $\mathrm{ND}$ & Agar + Glucose & 0.578 & 0.354 \\
Galactose & 1.118 & $\mathrm{ND}$ & Agar +Galactose & 0.435 & 0.388 \\
Fructose & 1.260 & $\mathrm{ND}$ & Agar +Fructose & 0.448 & 0.420 \\
Sucrose & 1.048 & $\mathrm{ND}$ & Agar +Sucrose & 0.236 & 0.328 \\
Mannose & 1.218 & $\mathrm{ND}$ & Agar +Mannose & 0.304 & 0.303 \\
Lactose & 1.130 & $\mathrm{ND}$ & Agar +Lactose & 0.911 & 0.330 \\
Maltose & 1.003 & $\mathrm{ND}$ & Agar +Maltose & 0.873 & 0.268 \\
\hline
\end{tabular}

ND-Not detected

This explains that the agarase production is inducible by agar/ agarose and production was reduced when co-supplemented with other simple carbohydrates, However catabolite repression was not observed.

Catabolite repression is a very common phenomenon observed in microorganisms, which regulate the production of enzymes of catabolic pathways, which in turn determines the extent of utilization of a compound by the microorganisms. Catabolite repression for agarase production was observed in Pseudomonas aeuroginosa AG LSL-11, in which agarase production was repressed when other carbon sources co-supplemented to agar [10]. Similar observations were reported in Alteromonas sp. (049/1) and Cytophaga saccharophila (024), in which agarase production was repressed when glucose was co-supplemented to agar [6]. In contrast, the co-supplemented simple sugars did not repress the agarase production in Pseudomonas aeuroginosa ZSL-2 and further fructose was found to enhance agarase production. This may be due to rapid utilization of simple sugars by the bacterium resulting in an increase in cell mass by vigorous growth.

The results with the one-factor-at-a-time method revealed that optimal conditions for the production of agarase were $24 \mathrm{~h}$ of fermentation period, $30{ }^{\circ} \mathrm{C}$ incubation temperature at $\mathrm{pH} 8.0$ with $\mathrm{NH}_{4} \mathrm{NO}_{3}$ as nitrogen source and agar as carbon source in MMS media. Among these four factors, temperature, $\mathrm{pH}, \mathrm{NH}_{4} \mathrm{NO}_{3}$ and agar with their relevant levels are selected for further optimization of agarase production by using orthogonal experimental design $\mathrm{L}_{9}$ $\left(3^{4}\right)$. The level-setting values of the factors used in the orthogonal array design are shown in Table 3 . 
Table 3. Factors and their levels employed in the $\mathrm{L}_{9}\left(3^{4}\right)$ in OATS for production of agarase by SmF of $P$. aeruginosa ZSL-2.

\begin{tabular}{lcccc}
\hline Level & $\begin{array}{c}\text { Factors } \\
\text { Temp } \\
\left({ }^{\circ} \mathrm{C}\right)\end{array}$ & $\begin{array}{c}\text { B } \\
\mathrm{pH}\end{array}$ & $\begin{array}{c}\mathbf{C} \\
\text { Nitrogen } \\
\left(\mathrm{g} . \mathrm{L}^{-1}\right)\end{array}$ & $\begin{array}{c}\mathbf{D} \\
\text { Carbon } \\
\left(\mathrm{g} . \mathrm{L}^{-1}\right)\end{array}$ \\
\hline level 1 & 28 & 7.5 & 1 & 1 \\
level 2 & 30 & 8.0 & 2 & 2 \\
level 3 & 32 & 8.5 & 3 & 3 \\
\hline & Nitrogen $-\mathrm{NH}_{4} \mathrm{NO}_{3}$ & & Carbon - Agar &
\end{tabular}

\section{2. Experimental results of $\mathrm{L}_{9}\left(3^{4}\right)$ orthogonal matrix method}

The optimal conditions for the culture parameters were obtained by using orthogonal design $\mathrm{L}_{9}\left(3^{4}\right)$ based on one factor at a time method. The effects of these factors on agarase production were analysed statistically as reported earlier [31] and results are shown in Table 4.

Table 4. $\mathrm{L}_{9}\left(3^{4}\right)$ Orthogonal array testing strategy (OATS) method for optimization of fermentation parameter for agarase production by SmF of $P$. aeruginosa ZSL-2.

\begin{tabular}{ccccccc}
\hline S. No. & A & B & C & D & Agarase activity U/ml \\
\hline 1 & $1\left(28^{\circ} \mathrm{C}\right)$ & $1(\mathrm{pH} .5)$ & 1 & 1 & 0.122 & \pm 0.003 \\
2 & $1\left(28^{\circ} \mathrm{C}\right)$ & $2(\mathrm{pH} 8.0)$ & 2 & 2 & 0.311 & \pm 0.009 \\
3 & $1\left(28^{\circ} \mathrm{C}\right)$ & $3(\mathrm{pH} 8.5)$ & 3 & 3 & 0.377 & \pm 0.011 \\
4 & $2\left(30^{\circ} \mathrm{C}\right)$ & $1(\mathrm{pH} .5)$ & 2 & 3 & 0.444 & \pm 0.013 \\
5 & $2\left(30^{\circ} \mathrm{C}\right)$ & $2(\mathrm{pH} 8.0)$ & 3 & 1 & 0.1 & \pm 0.003 \\
6 & $2\left(30^{\circ} \mathrm{C}\right)$ & $3(\mathrm{pH} 8.5)$ & 1 & 2 & 0.3 & \pm 0.009 \\
7 & $3\left(32{ }^{\circ} \mathrm{C}\right)$ & $1(\mathrm{pH} 7.5)$ & 3 & 2 & 0.188 & \pm 0.005 \\
8 & $3\left(32{ }^{\circ} \mathrm{C}\right)$ & $2(\mathrm{pH} 8.0)$ & 1 & 3 & 0.177 & \pm 0.005 \\
9 & $3\left(32{ }^{\circ} \mathrm{C}\right)$ & $3(\mathrm{pH} 8.5)$ & 2 & 1 & 0.366 & \pm 0.011 \\
${ }^{\mathrm{a}} K 1$ & 0.811 & 0.755 & 0.6 & 0.588 & & \\
$K 2$ & 0.844 & 0.588 & 1.122 & 0.8 & & \\
$K 3$ & 0.733 & 1.044 & 0.666 & 1 & & \\
${ }^{\mathrm{b}} k 1$ & 0.270 & 0.251 & 0.2 & 0.196 & & \\
$k 2$ & $\mathbf{0 . 2 8 1}$ & 0.196 & $\mathbf{0 . 3 7 4}$ & 0.266 & & \\
\hline
\end{tabular}




\begin{tabular}{lllll}
\hline$k 3$ & 0.244 & $\mathbf{0 . 3 4 8}$ & 0.222 & $\mathbf{0 . 3 3 3}$ \\
${ }^{\mathrm{c}} \Delta$ & 0.037 & 0.152 & 0.174 & 0.137 \\
$R$ & 4 & 2 & 1 & 3 \\
Opt & $\mathbf{A}_{\mathbf{2}}$ & $\mathbf{B}_{3}$ & $\mathbf{C}_{\mathbf{2}}$ & $\mathbf{D}_{\mathbf{3}}$ \\
\hline
\end{tabular}

The assignments of column A, B, C, and D were performed by orthogonal array consisted of nine experiments corresponding to the nine rows and four columns.

${ }^{\mathrm{a}} k_{i}=\sum k$ of all experiment at the same factor level.

${ }^{\mathrm{b}}$ Average of $k_{\mathrm{i}}$.

${ }^{\mathrm{c}} \Delta=\max \left\{\right.$ average of $\left.k_{i}\right\}-\min \left\{\right.$ average of $\left.k_{i}\right\}$.

Values are mean of triple determinations with standard deviation $( \pm)$.

Opt: optimization

In the present study, $\mathrm{L}_{9}\left(3^{4}\right)$ design was applied to screen the significant factors according to preliminary experiments. Four factors; agar, $\mathrm{NH}_{4} \mathrm{NO}_{3}$, temperature and $\mathrm{pH}$ and their relevant levels were selected for this study. The effect of these factors on agarase production were evaluated and analysed. Optimal conditions for the agarase production were; temperature of $30^{\circ} \mathrm{C}, \mathrm{pH} 8.5$, nitrogen source $\mathrm{NH}_{4} \mathrm{NO}_{3} 2 \mathrm{~g} \mathrm{~L}^{-1}$ and carbon source agar $3 \mathrm{~g} \mathrm{~L}^{-1}$. The order of effects of four factors on agarase production was $\mathrm{NH}_{4} \mathrm{NO}_{3}>\mathrm{pH}>$ agar $>$ temperature. According to the factor (Table 5), temperature had significant effect on the agarase production $(\mathrm{p}<0.10)$. These conditions were later tested to ascertain the reliability of these results. The agarase activity of $0.439 \mathrm{U} / \mathrm{mL}$ was produced which was higher than results in the orthogonal experiment.

Table 5. ANOVA of $\mathrm{L}_{9}\left(3^{4}\right)$ Orthogonal array testing strategy (OATS) for optimization of fermentation parameters for production by $\mathrm{SmF}$ of $P$. aeruginosa ZSL-2.

\begin{tabular}{ccccccc}
\hline & $\begin{array}{c}\text { Sum of } \\
\text { squares }\end{array}$ & df & $\begin{array}{c}\text { Mean of } \\
\text { square }\end{array}$ & $F$ value & Critical value & Significance \\
\hline Temperature & 7.224 & 2 & 3.612 & 3.978 & $F_{0.10}(2,8)=3.113$ & $*$ \\
pH & 0.0118 & 2 & 0.0059 & 0.0064 & & \\
Nitrogen & 0.0179 & 2 & 0.0089 & 0.0098 & \\
Carbon & 0.0093 & 2 & 0.0046 & 0.0051 & \\
Error & 7.2630 & 8 & 0.9078 & & & \\
\hline
\end{tabular}

df - Degree of freedom $\quad F$ value $-F_{0.10} \quad *$ Significant terms.

The orthogonal array design technique that has been successfully applied to improve the culture conditions for fermentation process and provides the relationships among various factors, and the order of significant factors for the optimum results [31-34]. In L9 orthogonal array method only 9 experiments were performed whereas, if factorial experimental design 
(Planket Burner design and central composite design) was used, at least 81 experiments in triplicate would be necessary to achieve the same results.

Very few reports have described the optimization of agarase production using one factor at time method $[10,12,14]$ reported optimisation of agarase production by statistical strategy using combination of Planket Burner design and central composite design (CCD). One-factor-at-a-time technique requires a considerable amount of time work. An alternative statistical strategy is to use factorial experimental design, orthogonal and response surface methodology (RSM), which involves a minimum number of experiments and covers large number of factors. These methods are also been employed to improve the production of microbial agarase in submerged fermentation.

\section{3. LC-ESI-MS analysis of agar hydrolysed products}

The mass spectra of the peaks indicated clearly that agar was hydrolysed initially by the action of extracellular agarases secreted by P.aeruginosa ZSL-2. The results of the LC-ESIMS analysis of the products revealed the presence of oligosaccharides ranging from mono- to octa- agar oligosaccharides. The products identified were anhydrogalactose (DA), Galactose (G), agarobiose, agarotetrose and agaroctaose. Signals observed at m/z 162.7 and $\mathrm{m} / \mathrm{z} 179.9$ were corresponds to the anhydrogalactose and galactose respectively. The signals observed at $\mathrm{m} / \mathrm{z} 325,631.1$ and 937.4 were corresponds to agrobiose, tetraose and octaose respectively (Table 6).

Table 6. LC-ESI-MS spectrometry analysis of agarase hydrolyzed products of Agar in culture supernatant by P.aeruginosa ZSL-2 grown for $24 \mathrm{~h}$.

\begin{tabular}{cc}
\hline Agar hydrolysed products & $\mathrm{m} / \mathrm{z}$ \\
\hline DA & 162.7 \\
G & 179.9 \\
$(\mathrm{DA}-\mathrm{G})$ & 325 \\
$(\mathrm{DA}-\mathrm{G})_{2}$ & 631.1 \\
$(\mathrm{DA}-\mathrm{G})_{3}$ & 937.4 \\
\hline
\end{tabular}

DA- anhydrogalactose, G-Galactose, (DA-G) -Biose, (DA-G) $)_{2}$-Tetraose and (DA-G) $)_{3}$-Hexaose

Agarases have been used for agar derived oligosaccharides production. Comparing to the traditional acid hydrolysis method, the enzyme hydrolysis methods have lot of remarkable advantages, such as tender reaction conditions, excellent efficiency, controllable products, simple facilities, low energy cost and little environment pollution.

Most of the reported agarases are endo-type enzymes that hydrolyse agar and agarose to give in order, neoagarohexose $\geq$ neoagarotetraose $\geq$ neoagarobiose as the main hydrolysis products, but majority of them do not cleave neoagarotetraose [35]. Oligosaccharides have been prepared using agar by crude agarase from Vibrio QJH-12 isolated from the South China Sea coast [36]. Two $\alpha$-agarases derived from marine bacteria Alteromonas agarlyticus GJ1B and Thalassomonas sp. JAMB-A33, have been reported to produce agarotetraose as the 
main product. Other $\beta$-agarases have been reported to produce neoagarobiose (NA2) [25,37,38] neoagarotetraose (NA4) [27,28] and neoagarohexaose (NA6) [39] as the predominant products. $\beta$ - Agarase from Acinetobacter sp. AG LSL-1 [40] has been reported to hydrolyse agarose into NA4, and NA6 and to NA2 as the only final product.

\section{CONCLUSION}

The agarases secreted by Pseudomonas aeruginosa ZSL-2 acted as endo enzymes and were capable of hydrolysing mainly agar into octaose, tetraose and biose which provides helpful tool to prepare agar oligosaccharides which have potential applications in food, pharmaceutical, and cosmetic industries.

\section{Acknowledgements}

This work was supported in part by research grant from Department of Science and Technology (DST), New Delhi, India (Project No. 100/IFD/5186/2007-2008 dated 6/11/2007). M. Ziayoddin is grateful to UGC for Junior Research Fellowship (MANF JRF (No.F.40-49(M)/2009(SA-III/MANF) dated 08 Jan 2011) and also to Gulbarga University, Gulbarga for laboratory facility.

\section{References}

[1] Kobayashi R., M. Takisada, T. Suzuki, K. Kirimura, S. Usami Biosci. Biotechnol. Biochem. 61 (1997) 162-163.

[2] Osumi Y., M. Kawai, H. Amano, H. Noda Nippon Suisan Gakkaishi 64 (1998) 98-104.

[3] Hu B., Q. Gong, Y. Wang, Y. Ma, J. Li, W. Yu Anaerobe. 12 (2006) 260-266.

[4] Lavilla-Pitogo C. R., Aquaculture 102 (1992) 1-7.

[5] Schroeder D. C., M. A. Jaffer, V. E. Coyne, Microbiology 149 (2003) 2919-2929.

[6] Agbo J. A. C., M. O. Moss, J. Can. Microbiol. 115 (1979) 355-368.

[7] Stanier R. Y., J. Bacteriol. 44 (1942) 555-570.

[8] Suzuki H., Y. Sawai, T. Suzuki, K. Kawai, J. Biosci. Bioeng. 95 (2003) 328-334.

[9] Hosoda A., M. Sakai, S. Kanazawa, Biosci. Biotechnol. Biochem. 67 (2003) 1048-1055.

[10] Lakshmikanth M., S. Manohar, J. Patnakar, P. Vaishampayan, Y. Shouche, J. Lalitha World J. Microbiol. Biotechnol. 22 (2006a) 531-537.

[11] Changkyou, J., K. Hyuckjin, P. Chulhwan, L. Jinwon, Biotechnol. Bioproc. Eng. 17(5) (2012) 937-945.

[12] Van der Meulen H. J., W. Harder, Antonie. Van. Leeuwenhoek. 41 (1975) 431-447.

[13] Hu Z., B. K. Lin, Y. Xu, M. Q. Zhong, G. M. Liu, J. Appl. Microbiol. 106 (2009) 181190.

[14] Fu X. T., H. Lin, S. M. Kim, Proc. Biochem. 44 (2009) 1158-1163. 
[15] Choi H. J., J. B. Hong, J. J. Park, W. J. Chi, M. C. Kim, Y. K. Chang, S. K. Hong, Biotechnol. Bioproc. Eng. 16 (2011) 81-88.

[16] Khambhaty Y., K. Mody, B. Jha, Biotechnol. Bioproc. Eng. 13 (2008) 584-591.

[17] Ziayoddin M., S. Manohar, J. Lalitha, The Bioscan. 5 (2010) 279-283.

[18] Dygert S., L. H. Li, D. Florida, J. A. Thoma, Anal. Biochem. 13 (1965) 367-374.

[19] Lowry O. H., N. J. Rosebrough, A. L. Farr, R. J. Randall, J. of Biol. Chem. 193 (1951) 265-275.

[20] Basawaraj A. K., S. Manohar, J. Lalitha, Biotechnology and Bioprocess Engineering 18 (2013) 333-341.

[21] Jean W. D., W. Y. Shieh, T. Y. Liu, Int. J. Syst. Evol. Microbiol. 56 (2006) 1245-1250.

[22] Hosoya S., Jae-Hyuk Jang, Mina Yasumoto-Hirose, Satoru Matsuda and Hiroaki Kasai Int. J. Syst. Evol. Microbiol. 59 (2009) 1262-1266.

[23] Andrykovitch G., I. Marx, App. Environ. Microbiol. 54 (1988) 1061-1062.

[24] Lakshmikanth M., S. Manohar, Y. Souche, J. Lalitha, World J. Microbiol. Biotechnol. 22 (2006b) 1087-1094.

[25] Morrice L. M., M. W. McLean, F. B. Williamson, W. F. Long, Eur. J. Biochem. 135 (1983) 553-558.

[26] Bae M.C., J. Kim, H. S. Shim, D. S. Byun, D. M. Cho, and H. R. Kim (2003). Second International Symposium on Fisheries Sciences and Technology for Academic Exchange between Hokkaido University and Pukyong National University, November 5, Hakodate, Japan.

[27] Vera J., R. Alvarez, E. Murano, J. C. Slebe, O. Leon, Appl. Environ. Microbiol. 64 (1998) 4378-4383.

[28] Leon O., L. Quintana, G. Peruzzo, J. C. Slebe, Appl. Environ. Microbiol. 58 (1992) 4060-4063.

[29] Sugano Y., I. Terada, M. Arita, M. Noma, T. Matsumoto, Appl. Environ. Mcrobiol. 59(5) (1993) 1549-54.

[30] Kim B. J., H. J. Kim, S. H. Ha, S. H. Hwang, D. S. Byun, T. H. Lee, J. Y. Kong Biotechnol. Letters 21 (1999) 1011-1015.

[31] Ziayoddin M., S. Manohar, J. Lalitha, J of Microbial and Biochemical Technology 4 (2012) 096-095.

[32] Bakhtiari M. R., M. G. Faezi, M. Fallahpour, A. Noohi, N. Moazami, Z. Amidi, Process Biochem. 41 (2006) 547-551.

[33] Krishna P. K., M. S. Venkata, R. R. Sreenivas, R. P. Bikas, P. N. Sarma, Biochem. Eng. J. 24 (2005) 17-26.

[34] Sreenivas R. R., R. S. Prakasham, P. K. Krishna, S. Rajesham, P. N. Sarma, R. L. Venkateswar, Proc. Biochem. 39 (2004) 951-956.

[35] Araki T., M. Hayakawa, L. Zhang, S. Karita, T. Morishita, J. Mar. Biotechnol. 6 (1998) 260-265. 
[36] Wang J., X. Jiang, H. Mou, H. Guan, J. Appl. Phyco. 16(5) (2004) 333-340

[37] Aoki T., T. Araki, M. Kitamikado, Eur. J. Biochem. 187 (1990) 461- 465.

[38] Fu X. T., H. Lin, S. M. Kim, Appl. Microbiol. Biotechnol. 78 (2008) 265-273.

[39] Wang J., H. Mou, X. Jiang, H. Guan, Appl. Microbiol. Biotechnol. 71 (2006) 833-839.

[40] Lakshmikanth M., S. Manohar, J. Lalitha, Proc. Biochem. 44 (2009) 999-1003. 